\title{
Edukasi Kesehatan Reproduksi pada Remaja untuk Menghadapi 1000 Hari Pertama Kehidupan
}

\author{
Desmawati \\ Program Study Ners Jurusan Keperawatan, FIKES, Universitas Pembangunan Nasional Veteran Jakarta \\ Email: desmawati@upnvj.ac.id
}

Submitted : 31/12/2019

Accepted: 05/01/2020

Published: $31 / 01 / 2020$

\begin{abstract}
Reproductive health education in female adolescent to face the first 1000 days of human life involving: knowledge about 270 days of pregnancy such as knowledge of pregnancy, assestment of pregnancy in health services, breast care, body and clothes hygiene, dental hygiene, imunization before and during of pregnancy, nutrition for female adolescent and pregnant women, taking early breastfeeding initiation, and continue to give exclusive breastfeeding. Knowledge for 730 days after delivery involving knowledge about health card for toddlers, immunization for baby, growth and development of child $0-23$ months, providing nutrition for 0-6 months and 7-24 months.The aim of this health services to improve knowledge of female adolescent about the first 1000 days of human life. This study methode using health education to increase knowledge of adolescent. The results revealed that health education and demonstration can improve the knowledge of female adolescent about the first 1000 days of human life.
\end{abstract}

Keyword: female adolescent, health education, the first 1000 days of human life

\begin{abstract}
Abstrak
Pendidikan kesehatan reproduksi pada remaja putri meliputi 270 hari pertama kehamilan seperti pengetahuan tentang kehamilan, pemeriksaan kehamilan di pelayanan kesehtan, perawatan payudara, kebersihan badan dan pakaian, kesehatan gigi, imunisasi sebelum dan selama kehamilan, nutriri untuk remaja putri sebelum hamil dan selama kehamilan, inisiasi menyusui dini, dilanjutkan dengan ASI eksklusif. Pengetahuan untuk 730 hari pertama setelah melahirkan menliputi pengetahuan tentang kartu sehat untuk bayi, imunisasi untuk bayi, pertumbuhan dan perkembangan anak usia 0-23 bulan, menyediakan nutrisi bayi 0-6 bulan dan 7-24 bulan. Tujuan pengabdian masyarakat ini untuk meningkatkan penegtahuan remaja putri tentang 1000 hari pertama kehidupan. Metode yang digunakan adalah Pendidikan kesehatan untuk meningkatkan pengetahuan remaja tentang 1000 HPK. Hasil pengabdian menunjukkan Pendidikan kesehatan bisa meningkatkan penegtahuan remaja putri tentang 1000 hari pertama kehidupan.
\end{abstract}

Kata Kunci: pendidikan kesehatan, pengetahuan, remaja putri, 1000 HPK.

\section{PENDAHULUAN}

Remaja di Cikulur masih banyak yang kurang mengetahui tentang kesehatan yang terkait dengan 1000 HPK, selesai jam pelajaran mereka tidak ada kegiatan akibatnya mereka banyak waktu luang yang sia-sia. Hasil penjajakan awal dengan memberikan mereka pertanyaan tentnag 1000 HPK, 60\% mereka tidak mengetahui apa itu 1000 HPK. Waktu luang yang siasia banyak digunakan oleh remaja untuk hal-hal yang tidak bermanfaat diantaranya tampak dari banyaknya remaja yang menghabiskan hari-harinya, hilir mudik mengemudi motor yang tidak ada tujuannya, serta bermain handphone dengan internetnya mengakses sesuatu yang tidak berfaedah untuk diri mereka dan masa depan mereka. Salah satu bentuk yang mereka mainkan di HP adalah permainan game yang tidak mendidik serta situs-situs pornographi yang akan berefek negative kepada kesehatan reproduksi mereka. Sebagian besar remaja tidak mengetahui 
efek negative mereka bermain situs porno, hanya memikirkan kenikmatan sesaat, Padahal efek dari waktu kosong mereka yang digunakan untuk merokok, main game, dan menonton situs porno akan mengakibatkan otak mereka teracuni oleh suatu hal yang disebut dengan "kecanduan", baik kecanduan merokok, bermain game, apalagi menonton situs porno. Akibat kecanduan tersebut mereka suatu saat bisa melakukan di dunia nyata seperti apa yang mereka tonton. Sehingga merusak kesehatan reproduksi mereka yang masih remaja notabenenya belum matur (matang) untuk dibuahi dan membuahi. Hasil membuahi inilah yang disebut dengan "hamil by accident" (hamil diluar nikah) yang akan membuat suram masa depan hidup mereka. Karena setelah kejadian itu, banyak yang tidak menikah, melahirkan tanpa ayah, abortus, membesarkan anak dengan menjadi pekerja seks komersial dan lain-lain. Apalah jadinya bangsa Indonesia, jika remaja-remajanya sudah musnah semangat hidup mereka sejak usia remaja, sedangkan Indonesia butuh generasi emas 2035 sebagai tonggak kejayaan bangsa tercinta ini. Untuk mencegah hal-hal yang tidak diinginkan di atas sangat perlu dilakukan implementasi dini kepada kelompok remaja di Cikulur. Diantara implementasi yang bisa dilakukan oleh tim pengabdi sebagai tenaga kesehatan adalah memberikan edukasi kepada remaja tentang "Pentingnya Kesehatan Reproduksi Remaja dalam menghadapi 1000 hari pertama kehidupan" karena 1000 hari pertama kehidupan merupakan masa yang menentukan untuk persiapan generasi emas maka itu merupakan program pemerintah yang sedang digalakkan yang dikenal dengan singkatan "1000 HPK" .

\section{TARGET DAN LUARAN}

Melihat khlayak sasaran dari mitra yaitu keadaan kehidupan remaja disana yang waktu luang sepulang sekolah dipakai untuk aktifitas yang sia-sia, diharapkan luarannya adalah dengan edukasi yang diberikan relative lebih menambah ilmu pengetahuan mereka tentang kesehatan reproduksi remaja, dan mempersiapkan hidup mereka menjadi lebih baik, lebih sehat, lebih produktif dan bisa menjadi bagian pembentuk generasi emas Indonesia 2035. Karena pengetahuan adalah faktor penting yang bisa mengubah seseorang dari tidak baik menjadi baik. Dengan pertimbangan alasan di atas maka tim pengabdi membuat pengabdian berupa "Implementasi edukasi kesehatan reproduksi remaja untuk menghadapi 1000 hari pertama kehidupan".

\section{METODE PELAKSANAAN}

Pertama kali yang dilakukan adalah Survey lapangan, ke dua melakukan persiapan berupa pembelian alat yang dibutuhkan untuk pelaksanaan point 1000 HPK, pembelian bahan untuk media edukasi dan menentukan langkah kerja. Ke tiga membuat materi edukasi dan pelatihan dan pelaksanan pelatihan, $\mathrm{Ke}$ empat demonstrasi dan praktek pelaksanaan pointpoint 1000 HPK: Pengetahuan mengenai tahapan $270 \mathrm{HPK}$ terdiri dari pengetahuan tentang masa kehamilan, pemeriksaan kehamilan pada pelayanan kesehatan, perawatan payudara, kebersihan tubuh dan pakaian, perawatan gigi, imunisasi sebelum dan selama kehamilan serta nutrisi saat hamil (demonstrasi makanan yang bergizi untuk remaja dan ibu hamil), melakukan Inisiasi Menyusu Dini (IMD), dan diteruskan dengan pemberian Air Susu Ibu (ASI) eksklusif. Pengetahuan tahapan 730 hari kehidupan meliputi pengetahuan tentang Kartu Menuju Sehat untuk Balita (KMS Balita), imunisasi untuk bayi, perkembangan anak usia 0 s/d 23 bulan, dan pemberian nutrisi usia 0-6 bulan dan usia 7-24 bulan (Agustina \& Desmawati, 2015; Sunarti, 2009). Ke lima yaitu pembuatan laporan akhir.

Bahan dan Alat yang Diperlukan: 
a. Nutrisi remaja: pembelian lauk, nasi, sayur, susu, buah, kompor, tabung gas, penggorengan, bahan dan alat masak lainnya

b. ASI eksklusif: tempat penampungan ASI, bantal, wadah penyimpanan ASI. Selain itu plif chart dan booklet diperlukan.

Langkah Kerja: 1) Mempersiapkan tempat penyuluhan, laptop dan LCD jika memungkinkan, 2) Mempersiapkan ruangan dan kelengkapan demonstrasi, 3) Mempersiapkan media edukasi, 4) Mempersiapkan semua peralatan dan bahan yang dibutuhkan untuk point-point 1000 HPK

a. Sediakan air hangat dalam kom dan minyak kelapa original pada tempatnya untuk perawatan payudara

b. Demonstrasikan cara memilih dan mengolah serta memasak sayur, lauk untuk nutrisi remaja dan ibu hamil

c. Peragakan cara menyiapkan ASI Perah

d. Demonstrasikan posisi menyusui

e. Demonstrasikan cara memberikan ASI kepada bayi dengan sendok ketika ibu ada di tempat kerja

f. Tekhnik posisi berhubungan untuk mendapatkan anak perempuan ataupun laki-laki bagi yang sudah menikah.

\section{HASIL DAN PEMBAHASAN}

Hasil luaran yang dicapai akan dipaparkan berikut ini, terkait pengumpulan data sebelum diberikan edukasi 1000 hari pertama kehidupan dan pengetahuan mreka setelah diberikan edukasi

\section{Gambaran data demografi remaja di Cikulur}

Tabel 1 Frekuensi dan persentase serta rata-rata data demografi remaja/i di Cikulur $(n=16)$

\begin{tabular}{lcc}
\hline Data demografi & $\mathrm{N}$ & $\%$ \\
\hline Usia [mean] (th) & 17,7 & \\
Level pendidikan & & \\
-SD & 11 & 68.75 \\
-SMP & 5 & 31.25 \\
Berat badan [mean] & 41,09 & \\
(kg) & & \\
\hline
\end{tabular}

\section{Pengetahuan remaja tentang 1000 HPK (270 HPK) di Cikulur}

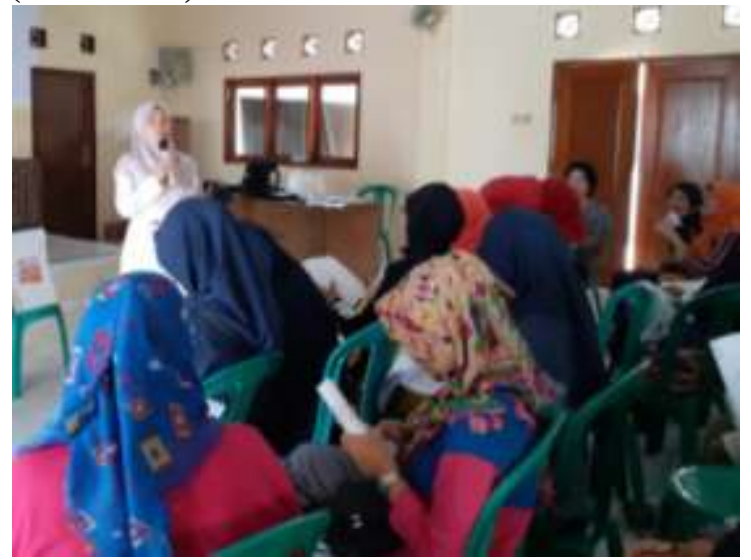

Gambar 1 pemberian Pendidikan kesehatan tentang 1000 HPK

Tabel 2 Distribusi pengetahuan remaja dalam menghadapi 1000 HPK (270 HPK)

\begin{tabular}{|c|c|c|c|c|c|}
\hline \multirow{2}{*}{\multicolumn{2}{|c|}{ Pertanyaan }} & \multicolumn{2}{|c|}{ Pre test } & \multicolumn{2}{|c|}{ Post test } \\
\hline & & $\mathrm{Jml}$ & $\%$ & Jml & $\%$ \\
\hline \multicolumn{6}{|c|}{$\begin{array}{l}\text { Pengetahuan tentang } \\
\text { masa kehamilan }\end{array}$} \\
\hline -benar & & 8 & 50 & 16 & 100 \\
\hline -salah & & 8 & 50 & 0 & 0 \\
\hline \multicolumn{6}{|c|}{ Pemeriksaan } \\
\hline $\begin{array}{l}\text { kehamilan } \\
\text { yankes }\end{array}$ & pada & & & & \\
\hline -benar & & 8 & 50 & 16 & 100 \\
\hline -salah & & 8 & 50 & 0 & 0 \\
\hline \multicolumn{6}{|c|}{ Perawatan payudara } \\
\hline -benar & & 5 & 31.25 & 16 & 100 \\
\hline -salah & & 11 & 68.75 & 0 & 0 \\
\hline $\begin{array}{l}\text { Kebersihan } \\
\text { dan pakaian }\end{array}$ & tubuh & & & & \\
\hline -benar & & 6 & 37.5 & 16 & 100 \\
\hline -salah & & 10 & 62.5 & 0 & 0 \\
\hline \multicolumn{6}{|c|}{ Perawatan gigi } \\
\hline -benar & & 3 & 18.75 & 16 & 100 \\
\hline -salah & & 13 & 81.25 & 0 & 0 \\
\hline \multicolumn{6}{|c|}{$\begin{array}{lr}\text { Imunisasai } & \text { sebelum } \\
\text { dan } & \text { setelah }\end{array}$} \\
\hline kehamilan & & 6 & 37.5 & 16 & 100 \\
\hline $\begin{array}{l}\text {-benar } \\
\text {-salah }\end{array}$ & & 10 & 62.5 & 0 & 0 \\
\hline \multicolumn{6}{|c|}{ Nutrisi saat hamil } \\
\hline -benar & & 4 & 25 & 16 & 100 \\
\hline -salah & & 12 & 75 & 0 & 0 \\
\hline \multicolumn{6}{|l|}{ IMD } \\
\hline -benar & & 6 & 37.5 & 16 & 100 \\
\hline -salah & & 10 & 62.5 & 0 & 0 \\
\hline $\begin{array}{l}\text { Pemberian } \\
\text { eksklusif }\end{array}$ & ASI & & & & \\
\hline -benar & & 2 & 12.5 & 16 & 100 \\
\hline -salah & & 14 & 87.5 & 0 & 0 \\
\hline
\end{tabular}




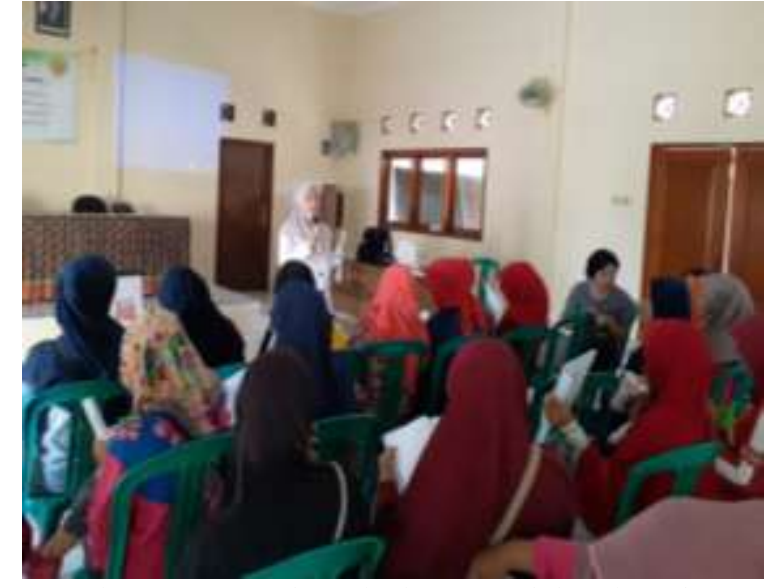

Gambar 2 Tanya jawab dan pengisian kuesioner seputar 1000 HPK

Pengetahuan remaja terkait 1000 hari pertama kehidupan ini dibagi menjadi dua tahap yaitu tahapan 270 hari pertama kehidupan jelas dapat dilihat pada tabel 2 diatas dengan item pertanyaan mengacu kepada point-point tahapan 270 HPK. Sedangkan tahapan ke dua yaitu 730 hari pertama kehidupan dengan item pertanyaan yaitu mengacu kepada point-point yang ada pada tahapan 730 HPK dapat dilihat dari table 3 berikut:

Tabel 3 Distribusi pengetahuan remaja dalam menghadapi 1000 HPK (730 HPK)

\begin{tabular}{lrrrr}
\hline Pertanyaan & \multicolumn{3}{r}{ Pre test } & \multicolumn{2}{r}{ Post test } \\
\cline { 2 - 5 } & Jml & $\%$ & Jml & $\%$ \\
\hline Pengetahuan tentang & & & & \\
Kartu Menuju Sehat & & & & \\
Balita & 8 & 50 & 16 & 100 \\
-benar & 8 & 50 & 0 & 0 \\
-salah & 5 & 37.5 & 16 & 100 \\
Imunisasi untuk bayi & & & \\
-benar & 11 & 62.5 & 0 & 0 \\
-salah & & & & \\
Perkembangan anak & & & & \\
usia 0-23 bulan & 4 & 25 & 14 & 75 \\
-benar & 12 & 75 & 2 & 25 \\
-salah & & & & \\
Pemberian nutrisi & & & & \\
usia 0-6 bulan & 6 & 37.5 & 16 & 100 \\
-benar & 10 & 62.5 & 0 & 0 \\
-salah & & & & \\
Pemberian nutrisi & & & & \\
usia 7-24 bulan & 2 & 12.5 & 16 & 100 \\
-benar & 14 & 87.5 & 0 & 0 \\
-salah & & & & \\
\hline
\end{tabular}

Pengetahuan remaja putri mengenai tahapan 270 HPK yang terdiri dari pengetahuan tentang masa kehamilan, pemeriksaan kehamilan pada pelayanan kesehatan, perawatan payudara, kebersihan tubuh dan pakaian, perawatan gigi, imunisasi sebelum dan selama kehamilan serta nutrisi saat hamil (demonstrasi makanan yang bergizi untuk remaja dan ibu hamil), melakukan Inisiasi Menyusu Dini (IMD), dan diteruskan dengan pemberian Air Susu Ibu (ASI) eksklusif meningkat setelah diberikan konseling. Begitu juga tampak peningkatan pengetahuan tahapan 730 hari kehidupan meliputi pengetahuan tentang Kartu Menuju Sehat untuk Balita (KMS Balita), imunisasi untuk bayi, perkembangan anak usia 0 s/d 23 bulan, dan pemberian nutrisi usia 0-6 bulan dan usia 7-24 bulan

\section{KESIMPULAN DAN SARAN 1.Simpulan}

Edukasi remaja untuk persiapan menghadapi 1000 HPK terbukti membantu meningkatkan pengetahuan remaja terkait 1000 HPK. Hal ini ditunjukkan dari setelah diberikan edukasi 1000 HPK terjadi peningkatan pengetahuan remaja tentang pengetahuan mengenai tahapan 270 HPK terdiri dari pengetahuan tentang masa kehamilan, pemeriksaan kehamilan pada pelayanan kesehatan, perawatan payudara, kebersihan tubuh dan pakaian, perawatan gigi, imunisasi sebelum dan selama kehamilan serta nutrisi saat hamil (demonstrasi makanan yang bergizi untuk remaja dan ibu hamil), melakukan Inisiasi Menyusu Dini (IMD), dan diteruskan dengan pemberian Air Susu Ibu (ASI) eksklusif. Pengetahuan tahapan 730 hari kehidupan meliputi pengetahuan tentang Kartu Menuju Sehat untuk Balita (KMS Balita), imunisasi untuk bayi, perkembangan anak usia 0 s/d 23 bulan, dan pemberian nutrisi usia 0-6 bulan dan usia 7-24 bulan. Edukasi 1000 HPK terbukti meningkatkan pengetahuan remaja 
tentang 1000 HPK, karena terbukti dari jawaban benar saat post test meningkat dibanding dengan pre test.

\section{Saran}

a. Remaja untuk selalu meningkatkan pengetahuan terkait 1000 HPK dengan belajar, ikut pelatihan, membaca buku terkait, diskusi dengan pakar terkait, dan lain-lain.

b. Pengabdi menyarankan juga kepada orang tua remaja untuk memberikan masukan, dukungan, dan ilmupengalaman kepada remaja, karena orang tua mereka sudah mengalami 1000 HPK saat melahirkan remaja putri tersebut

\section{UCAPAN TERIMA KASIH}

Terima kasih diucapkan kepada kepala desa Cikulur, karang taruna, ibu PKK, dan semua masyarakat Cikulur. Penulis juga mengucapkan terima kasih kepada rektorat dan LPPM yang telah memberi dukungan financial terhadap pengabdian masyarakat ini.

\section{DAFTAR PUSTAKA}

Agustina \& Desmawati. 2015. Gambaran pengetahan remaja akhir putri dalam kesiapan menyongsong 1000 hari pertama kelahiran. Bina Widya 4(11).

Badan Perencanaan dan Pembangunan Nasional.2012. Kerangka Kebijakan Gerakan Sadar Gizi dalam Rangka Seribu Hari Pertama Kehidupan. Jakarta: Bappenas.

Kementerian Kesehatan RI, 2013. Pedoman Gizi Seimbang (Pedoman Teknis Bagi Petugas dalam Memberikan Penyuluhan Gizi Seimbang

Kementerian Kesehatan RI. 2013.Rencana Kerja Program Gizi Masyarakat. Jakarta : Kementerian Kesehatan RI

Kementerian Kesehatan RI. 2012. Pedoman Perencanaan Program Gerakan Sadar Gizi dalam Rangka Seribu Hari Pertama Kehidupan (1000
HPK). Jakarta : Kementerian Kesehatan RI.

Kementerian Kesehatan RI. 2014. Profil Kesehatan Indonesia Tahun 2013. Jakarta : Kementerian Kesehatan RI.

Kementerian Kesehatan RI. 2014. Riset Kesehatan Dasar 2013. Kesehatan BPDP. Jakarta: Kementerian Kesehatan RI.

Kementerian Kesehatan. Riset Kesehatan Dasar 2010. Jakarta : Kementerian Kesehatan Republik Indonesia.

Notoatmodjo, S. 2010. Ilmu Perilaku Kesehatan Edisi Revisi. Jakarta: PT. Rineka Cipta.

Direktorat Jenderal Bina Gizi dan KIA KKR. Jakarta: Kementerian Kesehatan RI.

Potter, Patricia A. dan Anne Griffin P. 2010. Fundamental Keperawatan, Jilid II. Jakarta: Salemba Medika.

Pramudyta, Noeryda. 2013. Pengetahuan Remaja Putri tentang 1000 Hari Pertama Kehidupan di Wilayah Perkotaan dan Perdesaan Kabupaten Sumenep.

http://repository.ipb.ac.id/handle/123 456789/65060

Sunarti, E. 2009. Peningkatan Kepedulian Ibu, Kader dan Remaja untuk Perbaikan Status Gizi Anak. Bogor : Institut Pertanian Bogor. 